\title{
Supervisi Akademik Dalam Upaya Meningkatkan Motivasi Guru Menyusun Perangkat Persiapan Pembelajaran Untuk Pengembangan Profesionalitas Guru
}

\section{Innes Andriani}

\section{innesandriani99@gmail.com}

Penelitian ini bertujuan untuk mengetahui pengaruh penyelenggaraan supervisi akademik terhadap peningkatan motivasi guru dalam menyusun perangkat persiapan pembelajaran untuk pengembangan profesionalitas guru. Pendekatan peningkatan keprofesionalan guru tersebut dapat dilakukan dengan teknik supervisi, menumbuhkan budaya organisasi pembelajar, dan kegiatan pelatihan. Dengan menggunakan pendekatan tersebut, dapat dilakukan peningkatan kinerja lembaga melalui peningkatan keprofesionalan guru secara berkelanjutan baik yang dilakukan secara perorangan maupun kelompok. Penelitian dirancang dalam 3 siklus, yang masing-masing siklus terdiri dari kegiatan perencanaan, pelaksanaan, pengamatan, refleksi dan revisi. Tindakan yang dilakukan ialah supervisi yang dilanjutkan dengan penagihan komitmen dan bimbingan. Metode pengumpulan data yang digunakan ialah pengamatan dan wawancara. Sedang metode analisis data yang digunakan ialah metode diskriptif-comparatif.

Kata Kunci: supervisi akademik, motivasi, pembelajaran, pengembangan keprofesionalitas guru berkelanjutan

\section{LATAR BELAKANG}

Sebagaimana telah kita ketahui bersama bahwa tugas Guru Profesional, menurut Peraturan Pemerintah Republik Indonesia No. 74 tahun 2006, adalah menyusun perangkat pembelajaran, melaksanakan pembelajaran, melaksanakan penilaian pembelajaran, melaksanakan program perbaikan dan pengkayaan, melaksanakan analisis hasil penilaian dan melaksanakan tugas tambahan. Termasuk perangkat pembelajaran ialah kegiatan persiapan, yang meliputi kegiatan menyusun silabus, menyusun Rencana Pelaksanaan Pembelajaran (RPP), menyusun modul pembelajaran, dan menyusun media pembelajaran. 
Pendidikan adalah upaya yang secara sadar dirancang untuk membantu seseorang atau sekelompok orang dalam mengembangkan ilmu pengetahuan, pandangan hidup, sikap hidup, dan keterampilan hidup baik yang bersifat manual individual maupun sosial (Sagala, $2006: 1$ )

Masih dalam Nurul Yaqin (2004), Siagian berpendapat bahwa : "Motivasi adalah daya pendorong yang mengakibatkan seseorang anggota organisasi mau dan rela untuk menggerakkan kemampuan dalam bentuk keahlian atau keterampilan, tenaga dan waktunya untuk menyelenggarakan berbagai kegiatan yang menjadi tanggungjawabnya dan memfungsikan kewajibannya, dalam rangka pencapaian tujuan dan berbagai organisasi yang telah ditentukan sebelumnya". Secara konseptual, Supervisi akademik, ialah serangkaian kegiatan membantu guru mengembangkan kemampuannya mengelola proses pembelajaran demi pencapaian tujuan pembelajaran. Dengan demikian kegiatan supervisi adalah kegiatan yang positif dan mulia, yaitu membantu guru. Supervisi tidaklah berarti menilai kinerja guru, sehingga terkesan mencari atau menemukan kelemahan/kekurangan guru dalam melaksanakan pembelajaran, seperti kesan negatif yang selama ini tertanam dalam pandangan para guru.

Supervisi dilakukan dalam rangka menjamin pembelajaran yang berkualitas. Artinya, bahwa keberhasilan pelaksanaan supervisi diukur dari peningkatan prestasi belajar siswa. Penelitian Tenriningsih (2009) menemukan bahwa "terdapat hubungan langsung yang positif dan signifikan antara kinerja guru dengan prestasi belajar siswa dan terdapat hubungan langsung yang positif dan signifikan antara prestasi belajar siswa melalui supervisi pengajaran". Artinya semakin tinggi kinerja guru, semakin tinggi prestasi belajar siswa. Karena itu, untuk menghasilkan kinerja guruyang tinggi diperlukan supervisi pengajaran yang efektif.

\section{RUMUSAN MASALAH}

Bagaimana Pengaruh Supervisi Akademik Terhadap Peningkatan Kompetensi Guru Dalam Menyusun Perangkat Persiapan Pembelajaran?

\section{TUJUAN}

Mengetahui besarnya pengaruh penyelenggaraan supervisi akademik terhadap peningkatan kompetensi guru dalam menyusun perangkat persiapan pembelajaran. 


\section{PEMBAHASAN}

Berdasarkan data hasil tindakan dari siklus ke siklus, nampak ada perubahan atau perkembangan dari siklus 1 ke siklus 2, dan dari siklus 2 ke siklus 3. Bila pada siklus 1, jumlah guru yang menyerahkan dokumen silabus adalah 4 orang atau 33,33\%, maka pada siklus 2, jumlah guru yang sudah menyerahkan dokumen bertambah dengan 2 orang sehingga menjadi 6 orang guru atau 50\%. Selanjutnya pada siklus 3 jumlah guru yang menyerahan dokumen bertambah dengan 4 orang, sehingga jumlah seluruh guru yang sudah menyerahkan dokumen sampai dengan siklus 3 , menjadi 10 orang atau $83,3 \%$.

Dalam bentuk diagram batang, perkembangan jumlah guru yang sudah menyerahkan dokumen silabus dan RPP dari siklus ke siklus dapat digambarkan sebagai berikut :

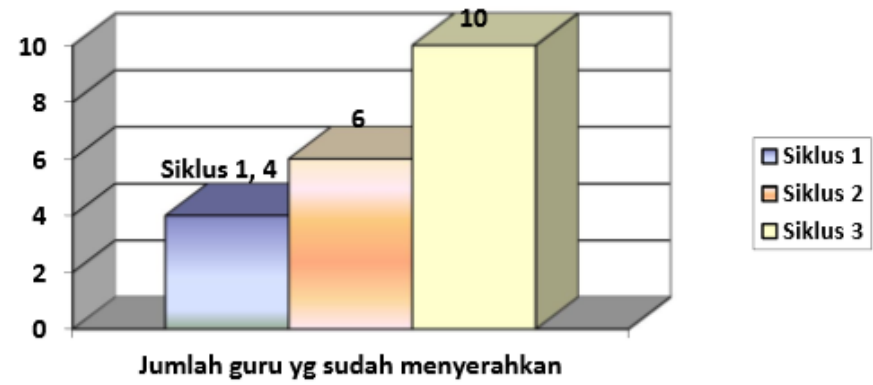

Data pada diagram batang tersebut menun jukkan adanya perubahan yang cukup signifikan, tentang motivasi guru dalam menyusun dokumen silabus dan RPP Kalau pada siklus 1, prosentase guru yang menyerahkan dokumen adalah sebesar 33,3\%, maka pada siklus 2 sudah menjadi 50\%, ada kenaikan sebesar 16,7\%. Selanjutnya pada siklus 3, prosentase jumlah guru yang menyerahkan dokumen menjadi83,3\%, naik sebesar 33,3\%. Kenaikan yang cukup signifikan ini memberi pelajaran bagi kita, bahwa pengaruh supervisi akademik yang dilakukan dengan prinsip humanis dan kolaboratif, dengan menagih komitmen dan bimbingan, cukup efektif untuk meningkatkan kinerja guru. Hal ini dapat dipahami, bahwa di satu sisi, memang kecenderungan watak dasar manusia adalah suka melampauhi batas dan dhalim, sehingga diperlukan pengendalian dengan menagih komitmen. Sedang di sisi lain, manusia juga cenderung suka bersikap bodoh, sehingga ia memerlukan bimbingan teknis pelaksanaan tugas. Dengan demikian, upaya meningkatkan kinerja guru, berkisar pada masalah bagaimana meningkatkan komitmen dan kompetensi. 


\section{KESIMPULAN}

Profesi guru adalah tugas mulia, yaitu mencerdaskan kehidupan bangsa, yang mestinya ditunaikan dengan niat mulia (komitmen) dan dengan keterampilan (kompetensi) memadai atau sesuai standar.Komitmen yang tinggi lahir dari hati yang suci, bersih, bersinar terang atau tidak terbelenggu oleh hawa nafsu. Selanjutnya hati yang suci akan menggerakkan perasaan, pikiran dan tindakan fisik untuk menimba banyak pengetahuan, keterampilan memadai dan sikap yang benar. Jadi komitmen tinggi akan melahirkan kompetensi tinggi. Upaya meningkatkan kinerja guru, dalam hal ini menyusun perangkat persiapan pembelajaran (yaitu silabus dan RPP), melalui penagihan komitmen dan bimbingan, terbukti efektif. Hal ini ditunjukkan dengan adanya peningkatan jumlah guru yang menyerahkan dokumen silabus dan RPP dari siklus 1 hingga siklus 3.

\section{SARAN}

Harapan kepada Dinas Pendidikan baik tingkat propinsi maupun daerah, untuk menyelenggarakan pembinaan kompetensi Kepala Sekolah dalam berbagai bidang, secara terus menerus, baik sekolah negeri maupun swasta, mengingat manfaatnya teramat besar serta kepada semua Guru, hendaklah menyadari dan memahami tugas mulianya dalam mencerdaskan kehidupan bangsa, dan ditunaikan dengan sungguh-sungguh (profesional)

\section{REFERENSI}

Rosilawati, T. (2014). Supervisi Akademik Dalam Upaya Peningkatan Motivasi Guru Menyusun Perangkat Persiapan Pembelajaran. Jurnal Penelitian Tindakan Sekolah dan Kepengawasan, 1(2), 1-6. Retrieved from http://irpp.com/index.php/jptsk/article/view/180.

Sabandi,A. (2013). Supervisi Pendidikan Untuk Pengembangan Profesionalitas Guru Berkelanjutan. Pedagogi, Jurnal Ilmiah Ilmu Pendidikan.XIII(2),1-9. Retrieved from http://ejournal.unp.ac.id/index.php/pedagogi/article/view/4275. 